\title{
FiLling the GaP? A Survey of Palestinian Case Law on Migration
}

\author{
Asem Khalil
}

CARIM Analytic and Synthetic Notes 2010/59

Legal Module 


\author{
CARIM \\ Euro-Mediterranean Consortium \\ for Applied Research on International Migration
}

\title{
Analytic and Synthetic Notes - Legal Module \\ CARIM-AS 2010/59
}

\author{
Asem Khalil* \\ Global Research Fellow, NYU School of Law
}

Filling the Gap?

A Survey of Palestinian Case Law on Migration

* Assistant Professor of Law at Birzeit University, Director of Abu-Lughod Institute of International Studies. 


\title{
(C) 2010, European University Institute \\ Robert Schuman Centre for Advanced Studies
}

This text may be downloaded only for personal research purposes. Any additional reproduction for other purposes, whether in hard copies or electronically, requires the consent of the Robert Schuman Centre for Advanced Studies.

Requests should be addressed to carim@eui.eu

If cited or quoted, reference should be made as follows:

[Full name of the author(s)], [title], CARIM AS [series number], Robert Schuman Centre for Advanced Studies, San Domenico di Fiesole (FI): European University Institute, [year of publication].

THE VIEWS EXPRESSED IN THIS PUBLICATION CANNOT IN ANY CIRCUMSTANCES BE REGARDED AS THE OFFICIAL POSITION OF THE EUROPEAN UNION

\author{
European University Institute \\ Badia Fiesolana \\ I - 50014 San Domenico di Fiesole (FI) \\ Italy \\ http://www.eui.eu/RSCAS/Publications/ \\ http://www.carim.org/Publications/ \\ http://cadmus.eui.eu
}




\section{CARIM}

The Euro-Mediterranean Consortium for Applied Research on International Migration (CARIM) was created at the European University Institute (EUI, Florence), in February 2004 and co-financed by the European Commission, DG AidCo, currently under the Thematic programme for the cooperation with third countries in the areas of migration and asylum.

Within this framework, CARIM aims, in an academic perspective, to observe, analyse, and forecast migration in Southern \& Eastern Mediterranean and Sub- Saharan Countries (hereafter Region).

CARIM is composed of a coordinating unit established at the Robert Schuman Centre for Advanced Studies (RSCAS) of the European University Institute (EUI, Florence), and a network of scientific correspondents based in the 17 countries observed by CARIM: Algeria, Chad, Egypt, Israel, Jordan, Lebanon, Libya, Mali, Mauritania, Morocco, Niger, Palestine, Senegal, Sudan, Syria, Tunisia, and Turkey.

All are studied as origin, transit and immigration countries. External experts from the European Union and countries of the Region also contribute to CARIM activities.

CARIM carries out the following activities:

- Mediterranean and Sub-Saharan migration database;

- Research and publications;

- Meetings of academics and between experts and policy makers;

- Migration Summer School;

- Outreach.

The activities of CARIM cover three aspects of international migration in the Region: economic and demographic, legal, and socio-political.

Results of the above activities are made available for public consultation through the website of the project: www.carim.org

For more information:

Euro-Mediterranean Consortium for Applied Research on International Migration

Robert Schuman Centre for Advanced Studies (EUI)

Convento

Via delle Fontanelle 19

50014 San Domenico di Fiesole

Italy

Tel: +390554685878

Fax: + 390554685755

Email: carim@eui.eu

\section{Robert Schuman Centre for Advanced Studies}

http://www.eui.eu/RSCAS/ 


\begin{abstract}
Since its establishment in 1994, the Palestinian Authority has shown great interest in changing the Palestinian legal system through direct legislative intervention, despite its limited territorial, functional and personal jurisdiction. Yet for migration issues, the legislative intervention has been the exception rather than the rule. Such legislative stagnation was accompanied by lack of policies for migration issues in general. The lack of such legislative intervention as much as the absence of clear policies in migration issues is the 'gap' the title of this paper refers to.

This paper questions the role of Palestinian courts in filling the gap, whether by making new laws or even by contributing to the formulation of new policies. Two cases in particular will be discussed: the status of UNRWA and the rights it has inside refugee camps; and the way Palestinian courts dealt with foreign courts' decisions, determining indirectly what is national.

An analysis of a research sample on migration-related cases shows clearly that the Palestinian judiciary do not seem to be playing (or to be willing to play) the role of rule- or policy-maker in migration issues. This gap is not necessarily disturbing as there is no legal vacuum. Palestinian judges always find their way through the existing laws inherited from previous regimes, still in force in the West Bank and the Gaza Strip. The decisions analyzed in the research sample, though reduced numerically, are rich in meanings and indicators. They reflect the changes the Palestinian Authority had introduced to the legal system of the West Bank and the Gaza Strip and demonstrate how Palestinians are moving towards an understanding of their identity that evolve around a territorial state-like entity.
\end{abstract}

\title{
Résumé
}

Depuis sa mise en place en 1994, l'Autorité palestinienne a montré un grand intérêt à modifier le système juridique palestinien à travers une intervention législative directe, en dépit d'une compétence territoriale, fonctionnelle et personnelle limitée. Cependant, en matière migratoire, l'intervention législative a été l'exception plutôt que la règle. Cette stagnation législative s'est accompagnée d'un manque de politiques sur les questions migratoires en général, d'où le titre de ce papier et l'utilisation du terme «gap».

Cet article examine le rôle des cours palestiniennes pour combler ce vide, soit en créant de nouvelles lois soit en contribuant à la formulation de nouvelles politiques. Deux thèmes sont traités en particulier: le statut de l'UNRWA et son rôle dans les camps de réfugiés; la manière dont les cours palestiniennes abordent les décisions judiciaires étrangères, déterminant indirectement ce qui peut être considéré comme national.

Une analyse de la jurisprudence en matière de migration révèle clairement que les tribunaux palestiniens ne semblent pas (ou ne veulent pas) jouer un rôle de législateur ou de décideur concernant les questions migratoires, ce qui n'est pas nécessairement gênant puisqu' il n’y a pas de vide juridique. Les juges palestiniens trouvent toujours leur voie à travers les lois existantes héritées des régimes précédents et toujours en vigueur dans la Bande de Gaza et en Cisjordanie. Les décisions analysées dans cette recherche, bien que peu nombreuses, sont riches de sens et d'information. Elles reflètent les changements que l'Autorité palestinienne a introduits dans le système juridique de la Bande de Gaza et la Cisjordanie et montrent la manière dont les Palestiniens s'acheminent vers une définition de leur identité qui évolue autour d’une entité territoriale quasi-étatique. 


\section{Introduction}

Since its establishment in 1994, the Palestinian Authority (PA) has shown great interest in changing the Palestinian legal system through direct legislative intervention, despite its limited territorial, functional and personal jurisdiction. ${ }^{1}$ By 2006 the Palestinian Legislative Council (the main legislative body in the territories under PA control) had adopted more than hundred new, modern and unified laws, ${ }^{2}$ while the Council of Ministers had adopted hundreds of bylaws. Following Hamas' victory in the second legislative elections in 2006, the Palestinian Legislative Council became paralyzed; and since then, no new laws have been adopted by the Palestinian Legislative Council. Instead, the PA President issued dozens of decree-laws. The rhythm of such exceptional legislative intervention increased following Hamas' coup in Gaza in 2007.

Whenever it comes to migration issues, ${ }^{3}$ the legislative intervention of the PA became the exception rather than the rule. In fact, a survey of the PA legislative texts shows that there are still areas related to migration where the Palestinian legislature did not intervene. ${ }^{4}$ Such legislative stagnation was accompanied by a lack of policies for migration issues in general. ${ }^{5}$

The lack of such legislative intervention as much as the absence of clear policies in migration issues is the 'gap' that the title of this paper refers to. This paper questions the role of Palestinian courts in filling this gap, whether by making new rules of law or even by formulating new policies. The object of investigation will be Palestinians' Supreme Courts' rulings related to migration. ${ }^{6}$ I skimmed the thousands of Court decisions made available by Birzeit University Institute of Law's Database (Al-Muqtafi), ${ }^{7}$ in order to individualize those dozens of court decisions that relate, in one way or another, to migration issues (hereafter the research sample). ${ }^{8}$ The objective will not be to

${ }^{1}$ For more about the limited jurisdiction of the PA, see Khalil, Legislating for Migration: The Anomalous Case of the Palestinian Authority 2006, 3.

${ }^{2}$ See, generally, Institute of Law 2009.

${ }^{3}$ For the purposes of this paper, 'migration issues' refers to questions that can be grouped under five different themes: (1) admission of the population; (2) residence and settlements in the national territory; (3) integration of migrants and rights of foreign nationals in general; (4) expatriates' relationship with their country of origin and, finally, (5) exit and end of stay.

${ }^{4}$ See previous reports that surveyed the legislative texts, adopted by the PA since 1994, the year of its establishment: Khalil, Legislating for Migration: The Anomalous Case of the Palestinian Authority 2006; Khalil, Palestine: the Legal Dimension of Migration 2007; Khalil, Palestine: the Legal Dimension of Migration 2009.

${ }^{5}$ In previous reports, I have dealt with PA's lack of policies when it comes to Palestinians expatriates see, e.g.Khalil, The Circulation of Palestinian Refugees and Migrants 2008, or to irregular migration in Palestine e.g. Khalil, Irregular Migration into and through the Occupied Palestinian Territory 2009, as well ashighly-skilled migration Khalil, Dealing with Highly-Skilled Migration: The Case of the Palestinian Authority 2010.

${ }^{6}$ The courts decisions considered within this research sample include judgments rendered by: (1) the West Bank Court of Appeal acting as highest level of adjudication in the West Bank until 2001 (i.e. when the Court of Cassation was created); (2) Gaza Supreme Court, acting as High Court of Justice, replaced by the PA Supreme Court upon its introduction to the Palestinian judicial system in 2001; (3) the PA Court of Cassation and Supreme Court of Justice since their creation in 2001. The changes in the Palestinian judicial system were introduced by PA Law of Civil and Commercial Procedures No. 2 of 2001. The text is available in English at: http://muqtafi2.birzeit.edu/en/Legislation/GetLegFT.aspx?LegPath=2001\&MID=13849

The Judiciary Law No. 1 of 2002 consolidated this new judicial structure. The text is also available in English at: http://muqtafi2.birzeit.edu/en/Legislation/GetLegFT.aspx?LegPath=2002\&MID=14053

${ }^{7}$ I have used first a digitalized research (using keywords in the body text of the decisions) followed by manual research in categories that are connected to migration. All courts' decisions are available at Birzeit Institute of Law's data base. AlMuqtafi is accessible online at: http://muqtafi2.birzeit.edu/ (Access depends on registration, which is free.

${ }^{8}$ Those 22 rulings that will be considered as the "research sample" are listed at the end of this paper, and some of them are available at the CARIM website: http://www.carim.org/index.php?callContent=400\&callCountry=2430. The rest can be consulted on Al-Muqtafi database. 
present the merits of these rulings; rather, it is to show what contribution these decisions made to migration issues or helping to set down the public policies in that direction.

Few judgments from the research sample tackled the rights and freedoms of foreign nationals in Palestine, ${ }^{9}$ and the right of Palestinians to move freely. ${ }^{10}$ The majority of judgments considered in the research sample dealt, instead, with: (1) the status of United Nations Relief and Works Agency for Palestine Refugees in the Near East (hereafter UNRWA) and the rights Palestinian refugees inside refugee camps in the West Bank and the Gaza Strip; and (2) the execution of foreign judgments in Palestine. For this reason I will limit my analysis to these two issues (Sections I and II). I will then conclude with general observations, based on an analysis of the research sample (Section III).

\section{UNRWA Status and Prerogatives in the Refugee Camps}

Three of the cases in the research sample dealt with the privileges and immunities of UNRWA officials. ${ }^{11}$ An explicit reference is made to the Convention on the Privileges and Immunities of the United Nations of $1946,{ }^{12}$ considered by the court to be binding laws, and, for that reason, applicable to UNRWA officials. The court made reference in particular to article V (especially sections 17, 18, 20 and 21) with regards to privileges and immunities of UN officials (in this case, UNRWA). ${ }^{13}$ The research sample shows that Palestinian courts simply assumed the applicability of the above mentioned convention on UNRWA officials, without questioning the status of UNRWA itself. ${ }^{14}$

${ }^{9}$ See Appellate Court Decision No. 56/96 (Civil Section / Ramallah) in which the court notes that a foreign national must obtain a permit from the authorities for lease of immovable property before the beginning of the fourth year of lease, as per Immovable Property (Lease and Sale by Foreigners) Law No.40 of 1953 (still in force in the West Bank) (article 2). It shall be noted that articles 3 and 4 of the law (No.40 of 1953) determine the conditions under which foreign nationals can own immovable property by sale and by inheritance Both articles were amended in later stage, respectively by Immovable Property (Lease and Sale by Foreigners) Amendment Laws No.12 of 1960 and No.2 of 1962. The Council of Ministers, according to Article 6, can permit ownership of immovable properties on the condition of reciprocity of treatment.

${ }^{10}$ See Supreme Court of Justice Decision No.3/2005 (Gaza) in which the court applied restrictively cases in which it is possible to limit Palestinians' freedom to move freely. It made reference to article 277 of Civil and Commercial Procedures Law No. 2 of 2001 and rejected the possibility of extending such powers to limit individuals except in the cases and according to the conditions stipulated in article 277.

${ }^{11}$ Appellate Court Decision No. 535/95 (Penal Section / Ramallah and Appellate Court Decision No. 352/98 (Penal Section / Ramallah) are interconnected and deals with immunities of UNRWA officials. Appellate Court Decision No. 430/99 (Civil Section / Ramallah) on the other hand referred to UNRWA, as an international organization, and for that reason enjoying immunity against judicial prosecution.

It should be noted that the Appellate court in the West Bank has become the highest court of adjudication, since Israeli occupation in 1967. In 2001, the PA adopts Civil and Commercial Procedures Law No.2 of 2001 in which a unified Court of Cassation will stand as last level of adjudication (for both West Bank and Gaza Strip). Article 225: "Cassation is available against final judgments rendered by the court of appeals when such judgments are based on a violation of law or on a mistake in its application or interpretation.” Article 226: “The parties may challenge any final judgment through cassation in the following cases: 1 . If nullity occurs in the judgment or in the procedures such as to affect the judgment. 2. If the judgment under challenge contradicts a previous judgment that acquired the force of res judicata and that was rendered towards the same parties on the same dispute.”

12 The convention is available at: http://www1.umn.edu/humanrts/instree/p\&i-convention.htm

${ }^{13}$ It should be noted that the legal basis for the privileges and immunities of the UN in the West Bank and the Gaza Strip can be traced back to the British mandate. The British High-Commissioner had adopted, indeed, already in 1947, the United Nations Immunities and Privileges Ordinance (published in Annex 1 of the Palestinian Official Journal during the British Mandate No. 1588 of 14/6/1947, pages 206-211). The Ordinance is still in force in both the West Bank and Gaza Strip and can be found at: http://muqtafi2.birzeit.edu/Legislation/LegCard.aspx?id=L07544

${ }^{14}$ Since the three courts' decisions cited above are undertaken in cases involving UNRWA officials in the West Bank, it is then legitimate to limit our concerns in what follows to questioning the status of UNRWA in the West Bank. 
UNRWA, a subsidiary organ of the UN, is an international agency that was established by UNGA Resolution 302(IV) of 8 December 1949. ${ }^{15}$ The West Bank and the Gaza Strip are within UNRWA's five areas of operation. UNRWA became operational in May $1950 .{ }^{16}$ By then, the West Bank was under Jordanian and the Gaza Strip under Egyptian rule.

The Palestinian Authority was established only in 1994, but the status of UNRWA, according to the legal system in force in the West Bank and the Gaza Strip, remained unaltered. In fact, the legal basis for the operation of UNRWA in the West Bank can be traced back to the agreement between the government of the Hashemite Kingdom of Jordan and UNRWA. ${ }^{17}$ In this agreement, the Jordanian government agrees, inter alia, to extend immunities and privileges to certain categories of UNRWA officials (Article 1) and to provide necessary documentation for their free movement from, within, and to Jordan (Article 2). ${ }^{18}$

The research sample also includes four court decisions that deal with property rights in refugee camps; two in the West Bank ${ }^{19}$ and two in the Gaza Strip. ${ }^{20}$ All four decisions concurred that UNRWA is the owner of houses and that refugees are granted only right of use, in accordance with UNRWA regulations. The justification for such a conclusion is nonetheless different in both cases, since the legal basis for both claims is different.

In the West Bank, the two decisions are connected since the second is the Court of Cassation's confirmation of the conclusions reached by the Appellate Court. The Appellate Court solemnly stated that a refugee who leaves the refugee camp (even if a '1967 refugee') loses his or her rights to immovable property inside the refugee camp. The reason for this is that their right of use for immovable property is based on permission or authorization from UNRWA. The Court refers explicitly to the institution of ebaha (permission) in civil law, as regulated in Article 836 of the Mejallat. ${ }^{21}$ Such right of use, accordingly, persists while the UNRWA authorization remains intact.

The court used the case as an opportunity to proclaim that UNRWA does not grant right of use over land but only over houses. The reason for this is simple: UNRWA does not own this land but rents it. The court did not explain this fact further. It is possible, however, to find a basis for this claim in article four of the above mentioned Agreement between the Government of the Hashemite Kingdom of Jordan and UNRWA. Accordingly, when it comes to the right over the land (where refugee camps are), UNRWA has only the right of use, not property rights.

Interestingly, a dissident judge opposed the majority, not in its conclusions in abstract (applicability of refugee Camps' regulations, and refugees' lost of rights in case of departure from the camp), but on the specific case where the departure of the appellant was not due to choice but rather to force majeur,

\footnotetext{
${ }^{15}$ The resolution is available at: http://unrwa.org/etemplate.php?id=241

${ }^{16}$ Bocco 2010, 231.

${ }^{17}$ The agreement was published in the Jordanian Official Journal No.1061 of 07/04/1951, page 943. A copy of the agreement on Al-Muqtafi database: http://muqtafi2.birzeit.edu/Legislation/LegCard.aspx?id=6901

${ }^{18}$ Although not directly connected to our main topic here, the other articles are also relevant: Article 3 deals with UNRWA policies concerning staff selection; article 4 deals with expenses and contributions of both parties to basic services inside refugee camps; article 5 deals with exemption of products dedicated for refugees in Jordan from taxes and customs; article 6 considers those products as property of UNRWA until they become property transferred to individuals; article 7 deals with the refugee census; article 8 deals with the future of UNRWA properties in case of the completion of its mandate; article 9 postpones for future agreement the determination of conditions for UNRWA's work and relief projects; in article 10 the government undertake to protect UNRWA's supplies, warehouses and facilities; article 11 regulates entry into force of the agreement.

${ }^{19}$ Appellate Court Decision No. 550/2000 (Civil Section / Ramallah) and Court of Cassation Decision No. 149/2005 (Civil Recourse/ Ramallah).

${ }^{20}$ Appellate Court Decision No. 190/2000 (Land Section / Gaza) and Court of Cassation Decision No. 41/2003 (Gaza).

${ }^{21}$ The Ottoman Civil Code still in force in both the West Bank and the Gaza Strip.
} 
that is the 1967 displacement, and the Israeli refusal to allow the appellant's return until 1995. This was exactly the point raised in front of the Court of the Cassation. In other words, the dissident judge did not object to the conclusions of the court related to UNRWA's ownership of the houses inside the refugee camps and the limitation of refugees' right of use of those houses while UNRWA's authorization persists.

The Court of Cassation confirmed the position held by the Appellate Court with regards to refugee camps and refused to consider the 1967 war as possibly derogating that rule. For the Court of Cassation, the fact that a refugee leaves the refugee camp, even if due to 1967 displacement, means that UNRWA can give the right of use to somebody else.

The cases involving conflict over property rights inside Gaza refugee camps are dealt with by Gaza courts. The Appellate Court ${ }^{22}$ simply confirmed what it deemed was "well settled", namely that the residents of houses inside a refugee camp do not have ownership rights over the house but only a right of use. UNRWA is considered the owner of those houses. This position was confirmed by Gaza's Court of Cassation. ${ }^{23}$

The Court of Cassation refers to the Appellate Court's decision (No.193/99), under its scrutiny, which considered that the refugees who live in the refugee camps do not have ownership rights. The court also made reference to a decree issued by the then President Arafat on 19 May 1999, forbidding the investigation of the ownership of immovable property inside refugee camps. ${ }^{24}$

\section{Execution of Foreign Courts’ Decisions}

The overwhelming bulk of court decisions considered in the research sample are related to the execution of foreign courts' decisions. ${ }^{25}$ Most of those cases took place in the West Bank, and were decided by the Appellate Court (Civil Section) before the entry into force of the unified PA Execution Law no.23 of $2005 .{ }^{26}$ In these cases, the court ${ }^{27}$ confirmed the continuation of the applicability of

\footnotetext{
${ }^{22}$ Appellate Court Decision No. 190/2000 (Land Section / Gaza).

${ }^{23}$ Court of Cassation Decision No. 41/2003 (Gaza).

${ }^{24}$ The author could not find this decision in the Palestinian Authority Official Journal and, accordingly, could not ascertain the authenticity of this information.
}

${ }^{25}$ Fourteen court decisions out of twenty two are issued in matters relating to the execution of foreign court decisions. Most of them were issued by the Civil Section of the Appellate Court of Ramallah: Appellate Court Decisions No. 451/96; No. 621/96; No. 273/99; No. 497/99; No. 530/2001; No. 709/2001; No. 498/96; No. 277/98; No. 248/2000. There are only two decision issued by the (West Bank) Civil Section of the Court of Cassation upon its establishment in 2001: Court of Cassation Decisions No. 189/2004 and No. 89/2005. There are two decisions issued by the Supreme Court in Gaza in its capacity of High Court of Justice: Decision No. 64/94 and No. 34/96. Finally there is one decision issued by the High Court of Justice (Ramallah Section) upon its establishment in 2001: Decision No. 7/2001.

${ }^{26}$ The execution of foreign court judgments was regulated by articles 36-39 of this new law. In particular article 36 reads as follows: “(1) An order may be issued forth in regard of the judgements, decisions and orders issued forth in a foreign country to be executed in Palestine under the selfsame conditions prescribed in such country for the execution of the Palestinian judgements, decisions and orders therein, provided that they do not contradict the Palestinian Laws or cause damage to the supreme national interest. (2) The order to execute the judgements, decisions and orders issued forth in a foreign country shall be requested through an action to be submitted before the Court of First Instance, within the jurisdiction of which the execution is to required, provided that the such judgements, decisions and orders are certified by the competent authorities in due form.” While article 37 reads as follows: "The order concerning execution may not take place except following the verification of the following: (1) That the courts of the State of Palestine are not solely competent of the adjudication of the dispute regarding which the judgement, decision or order has been issued forth, and that the foreign courts which issued it forth are competent thereof in conformity with the Rules of International Judicial Jurisdiction established in their Law. (2) That the judgement, decision or order has possessed the force of the order that has been judged in conformity with the law of the court which has issued it forth. (3) That the judgement, decision or order does not contradict a judgement, decision or order that had been issued in advance by a Palestinian court and that it 
(Jordanian) Foreign Judgments' Execution Law No.8 of 1952 (in force in the West Bank), ${ }^{28}$ whether in religious or regular foreign court decisions. The court ${ }^{29}$ justified this claim by making direct reference to Presidential Decree No.1 of $1994 .^{30}$

However, the relevance of such judicial intervention was not in the determination of the law in force in cases involving the execution of foreign decisions; but rather in its activism in settling down the framework for determining what is considered a foreign court decision for the purposes of the law. In the Palestinian case this is not an easy task. Indeed, Palestinian courts faced challenging questions in cases involving the execution of court decisions issued by Jordanian and Israeli judges; albeit challenges of a different nature.

The Palestinian courts, indeed, needed to decide cases where the execution of Jordanian Courts decisions is at stake, whether religious or civil courts. Article 2 of the law provides expressly that "the term "Foreign Judgment" in this law shall mean every judgment given by a court outside the Hashemite Kingdom of Jordan (including religious courts)..." ${ }^{31}$ How can it be possible now for Palestinian Courts to use Jordanian law No. 8 of 1952 in cases involving Jordanian Courts decisions, being considered as decisions made by foreign courts for the purposes of that same law?

One way out can be found in Appellate Court Decision No. 497/99 (Civil Section / Ramallah). The court refers to Riyadh Arab Agreement for Judicial Cooperation. ${ }^{32}$ The court assesses the fact that Jordan had signed the agreement on 16/7/1985 and Palestine declared its intention to ratify it on 28/11/1983. The court refers in particular to article 31 related to the execution of judgments between contracting parties. ${ }^{33}$

Another way out for Palestinian judges was to make reference to the then King Hussein's decision in 1988 when he ordered the unilateral severance of all legal and administrative links between Jordan and the West Bank. ${ }^{34}$ Palestinian judges used King Hussein decision (which was constitutional in nature, involving state structure, territory and jurisdiction) to reinterpret a preexisting laws. Palestinian judges have seemed to say, the Jordanian courts' decisions can now be considered as foreign court decisions in Palestine, even if Palestinian courts continue to apply Jordanian Law No. 8 of 1952.

A foreign court decision, for Palestinian judges, now refers to any decision issued by a court outside the Palestinian territories. But, what about the Gaza Strip? Should a court decision issued by Palestinian courts in the Gaza Strip be considered a foreign court decision for the purposes of Law No.

(Contd.)

does not include any contraventions of the public order or morals in Palestine.” An English version of the law is available at: http://muqtafi2.birzeit.edu/en/Legislation/GetLegFT.aspx?LegPath=2005\&MID=15138.

${ }^{27}$ See, i.e., Appellate Court Decision No. 451/96 (Civil Section / Ramallah) and Appellate Court Decision No. $621 / 96$ (Civil Section / Ramallah).

${ }^{28}$ Foreign Judgments' Execution Law No.8 of 1952 was expressly abrogated by (PA) Execution Law no.23 of 2005 (Article 171).

${ }^{29}$ In Appellate Court Decision No. 273/99 (Civil Section / Ramallah).

${ }^{30}$ Decree Regarding the Continuation of Application of Laws, Regulations and Decrees that were in Force in the Palestinian Territories, before the Fifth Day of June One Thousand Nine Hundred and Sixty Seven, until they are Consolidated (No.1), 1994. Available at: http://muqtafi2.birzeit.edu/Legislation/LegCard.aspx?id=9663

${ }^{31}$ Emphasis is mine.

32 Available at: http://www.unhcr.org/refworld/publisher,ARAB,,,3ae6b38d8,0.html.

${ }^{33}$ Palestinian judge referred to Riyadh Arab Agreement for Judicial Cooperation a second time in Court of Cassation Decision No. 189/2004 (Civil Section / Ramallah). The court tackles the issue of notification of persons having a known domicile abroad, whom process is required to be served. The court does not consider "diplomatic means" and "private post companies" as legitimate means of notification, on the light of article 18 (par.1) of (PA) Civil and Commercial Procedures Law No.2 of 2001. The Court of Cassation also referred to Riyadh Arab Agreement for Judicial Cooperation. However, contrary to Appellate Court Decision No. 497/99 (see supra), the Court of Cassation did not seem to agree on its character as binding international agreement because there was no proof that Palestine ratified it.

${ }^{34}$ See, i.e., Appellate Court Decision No. 621/96 (Civil Section / Ramallah). 
8 of 1952 (in force in the West Bank)? Or, do Palestinian territories, for the purposes of the above law, also include the Gaza Strip? Normally they should not, because the severance of links that took place in 1988 involved only the West Bank (including East Jerusalem), while the Gaza Strip was never under Jordanian control, and Jordanian Law No.8 of 1952 was never in force in the Gaza Strip.

In Decision No. 64/94 of the (Gaza) Supreme Court, acting as High Court of Justice, the Court confirmed that the Execution Section of the Central Court is responsible for executing foreign courts' decisions. The decision at stake is adopted from an Egyptian court (personal status section), revised by the Shari'a Appellate Court in Gaza, then registered by a judge at the Central Court, and the order of execution was issued. In its judgment, the court refers to articles 4 and 5 of Ordinance no.16 of $1929 .{ }^{35}$

It should be noted however that such ordinance deals with the reciprocal enforcement of court decisions between the government of Egypt and the government of Palestine (under mandate). In other words, it could be used only in cases involving the execution of Egyptian court decisions. Accordingly, deciding what is national and what is foreign for the purposes of the execution of courts decision could not be settled with reference only to British Mandate Ordinance no.16 of 1929, in the same way that it could not be settled by making reference to the Jordanian decision to sever all legal and administrative links with the West Bank.

In order to deal with national court decisions as referring to decisions issued by Palestinian courts in both the West Bank and the Gaza Strip and, as a consequence, foreign court decisions as referring to all the rest, there is a need to look elsewhere. Palestinian judges made reference to Oslo agreements themselves, where the West Bank and the Gaza Strip for the purposes of those agreements are considered as a "single territorial unit". ${ }^{36}$ This was the case in Decision No. 34/96, issued by (Gaza) Supreme Court acting as High Court of Justice. ${ }^{37}$ In particular, the court referred to Annex III - Article 4 - Paragraph 4(a) that reads as follows: "Israel and the Palestinian Authority will enforce judgments rendered by the judicial organs under the responsibility of the other Party, provided that the judicial organ concerned had the jurisdiction to render the judgment and further provided that the enforcement is not contrary to public policy. The execution office under the responsibility of Israel and the Palestinian Authority shall execute such judgments as if rendered by their own judicial organs." ${ }^{38}$

The reference to Oslo Agreements may have helped to resolve the problematic issue of the status of Gaza's Courts judgments in the West Bank, and vice versa. ${ }^{39}$ Above cited Article 4 - Paragraph 4(a) of Annex III may have clarified the way Palestinian courts deal with Israeli courts' decisions in theoretical terms. Things are though much more complicated than this. The determination of the status of a court decision is not an easy task in the PA since courts need to decide on cases that took place while the Palestinian Authority territorial jurisdiction was still - and, indeed is still - to be determined, since the redeployment of Israeli military forces took place gradually following the Oslo Agreements.

The cases considered in the research sample are related to the complicated issue of Israeli Court decisions involving the Palestinians of East Jerusalem. For Palestinians, East Jerusalem is an occupied

\footnotetext{
${ }^{35}$ Later on it was expressly abrogated by (PA) Execution Law no.23 of 2005. The decision refers also to the (Gaza) Supreme Court according to article 58 of the Proclamation of the Constitutional System for Gaza Strip of 1962. This proclamation was implicitly replaced by (PA) Basic Law of 2002, later on replace by the amended Basic Law of 2003.

${ }^{36}$ See article XI of the Israeli-Palestinian Interim Agreement of 28 September 1995. Available at: http://www.jmcc.org/Documentsandmaps.aspx?id=417

${ }^{37}$ The case involves the decision to execute an Israeli court decision issued before the entry into force of Oslo Agreements. The Palestinian Supreme Court made an explicit reference to the Gaza-Jericho Agreement (May 4, 1994) that was later on incorporated in the Interim Agreement (September 28, 1995).

${ }^{38}$ The text is available at: http://www.mfa.gov.il/MFA/Peace\%20Process/Guide\%20to\%20the\%20Peace\%20Process/GazaJericho\%20Agremeent\%20Annex\%20III

${ }^{39}$ Of course the adoption of the unified (PA) Execution Law no.23 of 2005 had resolved this problem for ever, since this law had abrogated different laws in the West Bank and the Gaza Strip and provided unified source of law for both territorial units.
} 
territory. This position is supported by many UN resolutions and by the facts of the1967 war and its aftermath. The research sample, nevertheless, included a limited number of cases, rich in meanings and worthy of analysis. ${ }^{40}$

The cases show clearly that Palestinian courts avoided executing (Israeli) Courts' Decisions of Jerusalem. ${ }^{41}$ For there was a lack of reciprocity of treatment (imposed by Article 7 (par.2) of Foreign Judgment Execution Law No.8 of 1952). Such argumentation is contradictory, though. While this helped Palestinian courts avoid the recognition of Israeli Courts in Jerusalem as 'foreign courts' for the purposes of Law No.8 of 1952, they have used the same law to justify their position. This means that they implicitly recognize the applicability of that law in cases executing Israeli courts' judgments (including those relating to Jerusalem)!

A different impression may be given from the reading of Appellate Court Decision No. 498/96 (Civil Section / Ramallah). This judgment is at the same time interesting and problematic. It tackles the issue of Israeli court decisions (Magistrate of Peace, Jerusalem) with regards to immovable property in territories under direct PA control (zone A) and territories under joint Israeli and Palestinian control (Zone B). The Court rejected abstract arguments based on national sovereignty and recognized that the Israeli presence and their annexation policies leave no space for individuals to do anything but use Israeli courts and committees in order to protect their properties. The decision of those courts and committees, despite the illegitimacy of the occupation, created acquired rights that are impossible for the Court to ignore.

In very recent decision, ${ }^{42}$ however, the court seems to accept a judgment issued by an Israeli court in Jerusalem in accordance with Foreign Judgments Execution Law No.8 of 1952. The Court, however, declared solemnly that a foreign court decision related to immovable property in territories under PA control has no legal power or consequences for Palestinian courts. While this position seems to avoid extending Palestinian courts' jurisdiction to East Jerusalem, in reality it does not provide a framework for future judgments because it is not clear what the territories under PA control are. What about cases involving immovable properties in Zone $\mathrm{C}$ in the West Bank, under complete Israeli control still? The research sample gives no hints for that question. It must be left aside for now, maybe for future research to deal with.

\section{Conclusion}

The analysis of the research sample shows clearly that the Palestinian judiciary does not seem to be playing (or, indeed, to be willing to play) the role of the substitute either for the legislative branch of government in legislating new rules of law, or for the executive branch of government in settling new policies related to migration. In other words, for Palestinian judges the gap that results from the lack of unified PA laws and policies does not mean a legal vacuum. Palestinian judges always find their way out through the existing laws inherited from previous regimes, still in force in the West Bank and the Gaza Strip.

For this reason, it is possible to conclude that, despite this paper's ambitious title, the research sample shows clearly that Palestinian judge are still dependent on existing legislation, enacted by the political authorities in place, with very limited space for maneuverability in areas that are not covered

\footnotetext{
${ }^{40}$ Besides the above cited Decision No. 34/96, issued by (Gaza) Supreme Court acting as High Court of Justice, the research sample included four other decisions: The Civil Section Appellate Court Decisions No. 498/96; No. 277/98; and No. 248/2000. Similarly Court of Cassation Decision No. 89/2005 (Civil Section / Ramallah) dealt with cases involving the execution of Israeli Courts' decisions.

${ }^{41}$ This is the case with Appellate Court Decision No. 277/98 (Civil Section / Ramallah) and Appellate Court Decision No. 248/2000 (Civil Section / Ramallah).

42 The Court of Cassation Decision No. 89/2005 (Civil Section / Ramallah).
} 
by (legislated) laws. The Palestinian judge - even when he/she decides cases not clearly supported by available legislation - often justifies his decision with an interpretation of whatever legislated laws are available or by making a general reference to 'law' or 'justice'.

Still, our analysis of the research sample has suggested some conclusions that can be summarized as follows:

1) When it comes to UNRWA, its position, its role and its prerogatives in the refugee camps, Palestinian judge seems to play a political role - rather than a legal one. Different courts' decisions applied political decisions without questioning them. In other words, the Palestinian judge seems to recognize the superiority of sovereign decisions - undertaken by political leadership - whenever it comes to UNRWA and the refugee camps. They deal with the decision of President Arafat (not to question property status inside the refugee camps) as having a legal validity.

2) Palestinian judges recognize the applicability of international law when it comes to UNRWA. Immunity means that UNRWA cannot be part of any litigation and that UNRWA officials enjoy immunity from penal persecution for actions undertaken in the exercise of their duties. Palestinian judges also treat UNRWA regulations as valid source of law to justify the recognition of property rights inside refugee camps to UNRWA and the prerogatives of UNRWA to grant the right of use to Palestinian refugees according to the criteria set down by the same organization.

3) Palestinian courts recognize, as a matter of fact, the impact of the Israeli occupation on Palestinians' return to their homeland. Palestinian judges do not distinguish for the purposes of Palestinian (Authority) law between a Palestinian from the West Bank and the Gaza Strip and a Palestinian refugee having obtained an ID number through family unification. For the purposes of Palestinian law, both categories of Palestinians are to be treated equally.

4) There are many cases involving the execution of foreign courts' decisions. Most relevant for our purposes are those cases involving the Israeli courts. It is recognized that the Palestinian courts are responsible for executing Israeli courts' judgments if rendered by their own judicial organs - a duty Palestinians accepted in the Oslo agreements. However, in cases involving East Jerusalem - deemed by Palestinians to be illegally occupied by Israel - the question of the validity of Israeli court judgments become much more complicated. The court, however, seems to deal with the occupation - and the annexation - as the reality on the ground. For purposes of justice the court was ready to deal even with such judgments for the acquired rights these judgments may have established.

\section{List of Courts Decisions Included in the Research Sample (in Chronological Order):}

- The Supreme Court in its capacity of High Court of Justice (Gaza):

- Decision No. 64/94 (Gaza)

- Decision No. 34/96 (Gaza)

- Appellate Court (highest Court in the West Bank for civil and penal matters until the creation of the Court of Cassation in 2001):

- Decision No. 535/95 (Penal Section / Ramallah)

- Decision No. 56/96 (Civil Section / Ramallah)

- Decision No. 451/96 (Civil Section / Ramallah)

- Decision No. 498/96 (Civil Section / Ramallah)

- Decision No. 621/96 (Civil Section / Ramallah)

- Decision No. 277/98 (Civil Section / Ramallah) 
- Decision No. 352/98 (Penal Section / Ramallah)

- Decision No. 273/99 (Civil Section / Ramallah)

- Decision No. 430/99 (Civil Section / Ramallah)

- Decision No. 497/99 (Civil Section / Ramallah)

- Decision No. 190/2000 (Land Section / Gaza)

- Decision No. 248/2000 (Civil Section / Ramallah)

- Decision No. 550/2000 (Civil Section / Ramallah)

- Decision No. 530/2001 (Civil Section / Ramallah)

- Decision No. 709/2001 (Civil Section / Ramallah)

- The Court of Cassation:

- Decision No. 41/2003 (Gaza)

- Decision No. 189/2004 (Civil Section / Ramallah)

- Decision No. 89/2005 (Civil Section / Ramallah)

- Decision No. 149/2005 (Civil Recourse/ Ramallah)

- The Supreme Court, in its Capacity of High Court of Justice:

- Supreme Court of Justice Decision No. 7/2001

- Supreme Court of Justice Decision No.76/2005

- Supreme Court of Justice Decision No.3/2005 (Gaza) 


\section{Bibliography}

Bocco, Riccardo. "UNRWA and the Palestinian Refugees: A History within History." Refugee Survey Quarterly 28, no. 2 \& 3 (2010): 229-252.

Institute of Law. Al-Islah Al-Kanuni Fi Falasteen: Tafkeek al-Estemar wa Bena Al-Dawla (Legal Reform in Palestine: Decolonization and State-Building). Birzeit: Institute of Law - Birzeit University, 2009.

Khalil, Asem. Dealing with Highly-Skilled Migration: The Case of the Palestinian Authority. Analytic and Synthetic Notes - Highly Skilled Migration Series: Legal Module CARIM - AS 2010/09, Florence: CARIM - Consortium for Applied Research on International Migration - European Univeristy Institute, 2010.

Khalil, Asem. Irregular Migration into and through the Occupied Palestinian Territory. CARIM Analytic and Synthetic Notes 2008/79 - Irregular Migration Series, Legal Module, San Domenico di Fiesole: Robert Schuman Centre for Advanced Studies, European University Institute, 2009.

Khalil, Asem. Legislating for Migration: The Anomalous Case of the Palestinian Authority. Analytical and Synthetic Notes 2006/11 - Legal Module, Florence: CARIM - RSCAS, EUI, 2006.

Khalil, Asem. "Palestine: the Legal Dimension of Migration." In Mediterranean Migration (20062007 report), edited by Philippe Fargues, 195-205. 2007.

Khalil, Asem. "Palestine: the Legal Dimension of Migration." In Mediterranean Migration (20082009 report), edited by Philippe Fargues, 267-277. Florence: CARIM - RSCAS, EUI, 2009.

Khalil, Asem. The Circulation of Palestinian Refugees and Migrants. Analytical and Synthetic Notes 2008/33, Circular Migration Series, Legal Module, CARIM - RSCAS, EUI, 2008. 